$10.21867 / \mathrm{KjK} / 2016.2 .2$.

\title{
MIGRÁCIÓS KIHÍVÁSOK - HIÁNYZÓ EURÓPAI VÁLASZOK?
}

\section{Madai Sándor ${ }^{1}$}

Az erősödő migrációs nyomás válaszokra késztette Európát. Úgy tünik azonban, hogy ezek a válaszok közel sem egységesek. Sőt, lassan Európán is túlnyúlnak, hiszen a 2015. évi ENSZközgyülésen is több politikus felszólalásának központi eleme volt a probléma. Az EU-ban megfigyelhető szerteágazó megoldási elképzelésekben azonban szükségszerüen közös pont a válság rendészeti úton történő mederben tartása. Tudjuk, s ezt az európai döntéshozók is pontosan tudják, hogy a válság hosszú távú megoldása kizárólag a migránsokat kibocsátó országok politikai-gazdasági stabilizálása lehet. Ennek bekövetkeztéig azonban kezelnünk kell azokat a társadalmi feszültségeket, amelyek együtt járnak e jelenséggel, s indulatokat szítanak a befogadó államokban. Ez nyilvánvalóan rendészeti feladat is. Gondoljunk csak bele! Milyen jelentős volumenű plusz erőforrásokat igényel a helyzet kezelése? S ezeket honnan teremtik elő az érintett kormányok? Kizárólagos felelőssége van az egyes tagországoknak a helyzet kezelésekor, vagy esetleg az EU humánerőforrás terén, financiális oldalról, s egyáltalán politikai kooperációban gondolkodik? Nyilván igen, azonban jelenleg több elképzelés látott napvilágot, $\mathrm{s}$ ezek között jelentős hangsúlyeltolódások figyelhetőek meg. A bejegyzés arra a kérdésre keresi a választ, hogy milyen tendenciák figyelhetők meg a migrációs kérdéssel összefüggésben - a rendészeti közszolgáltatások szervezését illetően a jövőben.

A problémát abban érezzük, hogy az Európai Uniónak egyfelöl egy egységes stratégiát kell felállítani és képviselni, ugyanakkor az egyes tagállamok nem egyenlő mértékben érintettek, s saját belső politikai meggyőződésük szerint reagálnak a kihívásokra. Mire vezethető vissza az eltérő érintettség? Egyfelől a migrációs jelenség őket érintő tartamára, másfelől arra a kérdésre, hogy tranzitországként vagy célországként tekintenek-e rájuk a migránsok. Az első szempont szerint hosszú ideje érintett például Spanyolország, Olaszország, Görögország, mint a Délről, illetőleg Keletről kiinduló migrációs útvonal első EU-s állomásai. Tranzitországként relatíve új keletủ jelenség - legalább is a volumene a jelenségnek új - a migrációs probléma például Magyarországon, Horvátországban, Szlovéniában. Nyilvánvaló tény, hogy minél régebb óta kell szembesülnie egy tagállamnak a növekvő migráció kérdésével, annál rutinosabbá válhat annak kezelésében, mert volt ideje arra, hogy kifejlessze a kezelési technikáit. A korábban kisebb mértékben érintett államok - úgy tünik - váratlan kihívásként szembesültek a növekvő számú érkezőkkel, s kénytelenek prompt válaszokat adni, hiszen nincs idő a felkészülésre. E válaszok - miként már fent utaltunk rá - jelentős mértékben függnek a belső politikai viszonyoktól, hiszen nem ritkán egy-egy választási győzelem múlhat az adekvát, de legalább is a tagállam választópolgárai által adekvátnak tekintett válaszokon...

Szintén a tagországok közötti különbségtételre ad alapot azok mérete is. Egy nagyobb tagállam - különösen, ha esetében nem újkeletü a jelenség- talán könnyebben tudja kezelni s most kizárólag a rendészeti jellegü kezelésröl beszélünk - a nagyszámú migránst, hiszen területénél fogva egyébként is nagyobb rendészeti apparátus áll rendelkezésére, illetőleg talán nagyobb forrást is hozzá tud/akar rendelni a probléma kezeléséhez. Magyarországot érintően Kontrát Károly, a Belügyminisztérium parlamenti államtitkára jegyezte meg még 2015 augusztusában, hogy Magyarország erőn felül teljesít, és a legtöbbet teszi az uniós országok közül a schengeni határok védelmében. Szerinte a lakosságszám és a bruttó hazai termék

\footnotetext{
${ }^{1}$ Madai Sándor, tanszékvezető egyetemi docens, De ÁJK
} 
(GDP) figyelembevételével Magyarországra hárul a legnagyobb teher az illegális migráció miatt. $^{2}$

Úgy véljük ugyanakkor, hogy a cél-tranzit szerinti differenciálás további szempontot is involvál az érintett országok teherviselésé és a feladatellátás jelegét illetően. A tranzitországok tekintetében - ahol a továbbutazni szándékozó migránsok csupán néhány napot, esetleg néhány órát töltenek - kiemelt jelentőségünek véljük a rendészeti szempontok előtérbe helyezését, a logisztikai-ellátási feladatok mellett. E körben a rendészeti feladatok tükröződnek például az EU-s, s hazai normák betartásában-betartatásában, s az esetleges klasszikus rendészeti - közbiztonságot fenntartó/helyreállító - feladatok ellátásában, hiszen az éhség, fáradtság, bizonytalanság, elkeseredettség stb. emberi természetre gyakorolt hatásából következően az ilyen válaszokat igénylő magatartások veszélye fennáll. Ez indokolhatja más tényezők mellett - az élőerős, komoly létszámú jelenlétet is a határon. Utóbbi kört érintő magyar példa a 2015. október 23-i nagyfai fogolyzendülés. ${ }^{3}$ Ehhez képest a célországok az elsődleges rendészeti feladatokon túlpolitikai-menekültügyi-szociális feladatokat is vállalnak.

Az EU érzékelve a kihívást új migrációs stratégiát készített. Az új migrációs stratégia négy pillére ${ }^{4}$ :

1) Az illegális migráció kiváltó okainak csökkentése. Ennek keretében az uniós küldöttségek részeként európai migrációs összekötő tisztviselők kiküldésére kerülne sor a migrációs szempontból kulcsfontosságú harmadik országokba; a FRONTEX szerepének megerősítése; új cselekvési terv, amelyek célja, hogy az embercsempészés a jövőben kevéssé nyereséges és komoly kockázattal járó bünözői tevékenységnek minősüljön; valamint az okok megszüntetése fejlesztési együttműködés és humanitárius segítségnyújtás révén.

2) Határigazgatás: életmentés és a külső határok biztosítása. Ehhez szintén nélkülözhetetlen a FRONTEX megerösítése; segítségnyújtás harmadik országoknak ahhoz, hogy saját határigazgatási kapacitásukat erősíteni tudják; illetőleg, amennyiben szükséges, az egyes parti örségi funkciók összefogása uniós szinten;

3) Európa kötelezettsége a védelem nyújtására: erős közös menekültügyi politika. Ennek kapcsán elsődleges cél a közös európai menekültügyi rendszer erösítése, mindenekelőtt a migránsok szisztematikus azonosítása és az ujjlenyomatvétel elősegítése, valamint a visszaélések csökkentésére tett erőfeszítések által; a Dublini Rendelet esetleges felülvizsgálata 2016-ban;

4) A jogszerú migrációval kapcsolatos új szakpolitika. A fentiek mellett ugyanakkor az EU-nak az is célja, hogy a fogyatkozó népességü Európa továbbra is vonzó célpontot jelentsen a migránsok számára. Ehhez a kékkártyarendszer átgondolására van szükség, újra kell gondolni az Unió integrációs politikáját, illetve maximalizálni kell a migrációs politika által nyújtott előnyöket az egyének és a származási országok számára, többek között az olcsóbb, gyorsabb és biztonságosabb készpénzátutalások elösegítése révén.

\footnotetext{
${ }^{2}$ http://hvg.hu/itthon/20150817_Kimaradunk_az_EUs_hatarvedelmi_akciokbol.

${ }^{3}$ Eltorlaszolták zárkáik ajtaját a nagyfai ideiglenes befogadóállomáson tiltott határátlépés miatt idegenrendészeti őrizetben lévő és kiutasításra váró menekültek. Az egész nap tartó erőszakos cselekmények során - amelyekben csaknem hetvenen vettek részt - a fogvatartottak tönkretették a zárkák fütését, kitörték az ablakokat, nem fogadták el az élelmet, és éhségsztrájkkal is fenyegetőztek. Csak késő estére sikerült meggyőzni őket arról, hogy nyissák ki a helyiségeket.http://hvg.hu/itthon.bunugy/20151026_zendules_volt_nagyfan.

${ }^{4} \mathrm{http} / /$ europa.eu/rapid/press-release_IP-15-5700_hu.htm.

${ }^{5}$ Az Európai Unió tagállamainak külső határain való operatív együttmüködési igazgatásért felelős európai ügynökség.
} 
Láthatjuk, hogy ezek hosszabb távú célkitüzések, nem egy közülük jogi aktus életre hívását is igényli. Ez időt vesz igénybe, de mit tesz az EU az aktuális helyzettel, ad-e vajon rapid válaszokat a kihívásokra? A válasz igen. A fenti hosszabb távú, koncepcionális jellegü $-\mathrm{s}$ rendészeti elemeket is tartalmazó ${ }^{6}$ - megközelítés mellett, a napjaink elvárásainak is meg kell felelni.

Az azonnali intézkedések keretében 2015 folyamán az Európai Unió több intézkedést tett/tesz - most azonban kizárólag a rendészeti célú elképzelésekre fókuszálunk ${ }^{7}$ :

- A Triton és Poszeidón müveletekhez ${ }^{8}$ rendelt kapacitás és eszközök megháromszorozása 2015-ben és 2016-ban. 2015 tekintetében 2015. május 13-án költségvetés-módosítást fogadtak el a szükséges finanszírozás biztosítására (összesen 80 millió EUR).

- Javaslat az EUMSZ 78. cikke (3) bekezdésének megfelelő vészhelyzeti mechanizmus első alkalommal történő aktiválására azon tagállamok támogatása érdekében, amelyek migránsok hirtelen beáramlásával szembesülnek. Május végéig a Bizottság egy átmeneti elosztási mechanizmusra tett javaslatot, amely az Unión belül egyértelmüen nemzetközi védelemre szoruló személyekre irányul. A tömeges beáramlás miatt kialakult szükséghelyzetekben történő áthelyezésre irányuló állandó uniós rendszerre vonatkozó javaslatot szintén előterjesztette ${ }^{9}$, amellyel kapcsolatban több tagország ellenvéleményét fejtette ki.

- Sor került közös biztonság- és védelempolitikai műveletet kidolgozása a földközitengeri térségben az emberkereskedelmi hálózatok és az embercsempészet nemzetközi joggal összhangban történő felszámolására.

- 1,3 millió EUR a FRONTEX, az $\mathrm{EASO}^{10}$ és az Europol ${ }^{11}$ uniós ügynökségek személyzete létszámának növelésére. ${ }^{12}$

- Tervezi az Unió a legjelentősebb rendészeti arculatú változást: az európai határ- és parti őrség létrehozását, valamint a FRONTEX megbízatásának kibővítését. Ezen intézkedés mind szemléletbeli, mind strukturális változást fog eredményezni az Unió eddigi határrendészeti politikájában.

Gyakori kritikaként hangzott el a közelmúltban, hogy az EU-nak nincs koncepciója a migránshelyzet kezelésére. Való igaz, hogy úgy tünhet, mintha nem lenne, illetőleg nem lenne hatékony. Létezik ilyen irányú elképzelése, viszont a döntési folyamatok lassúsága alapvetően megnehezíti azt, hogy gyors és adekvát válaszokat hozzon egy-egy ilyen kérdés tekintetében, különösen úgy, hogy gyakran számos érdeket kell összehangolni a döntést megelözően. Szintén úgy tünik, hogy egyes tagállamok saját elképzeléseiket megvalósítva próbálják határaikat védeni, illetve a területükre történő belépést, az azon való áthaladást kontrollálni. ${ }^{13}$ Úgy véljük, hogy a rendészeti célú intézkedések tagállamok általi végrehajtása nem nélkülözhető a helyzet kezeléséhez, ugyanakkor a hosszú távú megoldások már messze túlmutatnak a rendészeti válaszokon, $\mathrm{s}$ olyan globális, politikai válaszokat igényelnek, amelyek jelenleg még a jövő ködébe vesznek.

\footnotetext{
${ }^{6}$ Lásd pl. a FRONTEX szerepének egyértelmű erősítését célzó törekvéseket.

${ }^{7}$ Az európai migrációs stratégia - A helyzet állása: 2015. október 14-én, Európai Bizottság, 2015

${ }^{8} \mathrm{~A}$ két múvelet a FRONTEX által koordinált, ellátott határőrizeti célú feladat, klasszikus határrendészeti tevékenység. A Triton a Földközi-tenger középső részére, míg a Poszeidon a Földközi-tenger keleti részére irányul.

${ }^{9}$ E tervvel kapcsolatban a magyar kormánynak is vannak fenntartásai.

http://hvg.hu/vilag/20150914_Orbannak_atmenetileg_sikerult_megfurnia_a

${ }^{10}$ Európai Menekültügyi Támogatási Hivatal.

${ }^{11}$ Európai Rendőrségi Hivatal.

${ }^{12} \mathrm{~A}$ három szervezet közül a FRONTEX és az Europol kifejezetten rendészeti célú szervezet.

${ }^{13}$ Lásd például a magyar müszaki határzárat, melynek megépítését Ausztria saját határán is tervezi.
} 